Original Article

\title{
Amelioration of Carcinogen-Induced Toxicity in Mice by Administration of a Potentized Homeopathic Drug, Natrum Sulphuricum 200
}

\author{
Nandini Bhattacharjee, Surajit Pathak and Anisur Rahman Khuda-Bukhsh \\ Cytogenetics and Molecular Biology Laboratory, Department of Zoology, University of Kalyani, Kalyani-741235, \\ India
}

\begin{abstract}
To examine if a potentized homeopathic drug, Natrum Sulphuricum 200 (Nat Sulph-200) has protective potentials against hepatocarcinogenesis, liver tumors were induced in mice through chronic feeding of $P$-dimethylaminoazobenzene (p-DAB; initiator of hepatocarcinogenesis) and phenobarbital (PB; promoter). Mice were divided into five sub-groups: fed normal low protein diet (Gr. I, normal control); fed normal low protein plus alcohol-200 (vehicle of the homeopathic remedy) (Gr. II); fed diet mixed with $0.06 \%$ p-DAB plus $0.05 \%$ PB (Gr. III); fed diet and carcinogens like Gr.III, plus alcohol 200 (positive control for drug fed mice) (Gr. IV) and fed diet and carcinogens like Gr. III, plus Natrum Sulphuiricum-200 (Gr. V; drug fed). Mice were sacrificed at day 7, 15, 30, 60, 90 and day 120 for study of cytogenetical endpoints like chromosome aberrations (CA), micronuclei (MN), mitotic index (MI) and sperm head anomaly (SHA) and biochemical toxicity parameters like aspartate amino transferase (AST), alanine amino transferase (ALT), acid (AcP) and alkaline (AlkP) phosphatases, lipid peroxidation (LPO) and reduced glutathione (GSH) content. Less number of liver tumors were observed in Gr. V (drug fed) mice. Administration of Nat Sulph 200 reduced genomic damage, activities of AcP, AlkP, AST, ALT, LPO and increased GSH content. Therefore, independent replication of the study by others is encouraged.
\end{abstract}

Keywords: anti-carcinogenesis - azo dye induced liver cancer - geno- and cyto-toxicity biomarkers homeopathic remedy - mice

\section{Introduction}

Complementary and alternative medicine (CAM) is one of the growing areas in health care today (1-4), particularly as supportive medicine in treating difficult to cure diseases like cancer (5-7). Homeopathy is becoming one of the popular alternative modes of treatment (8-10). Because of ultra high dilutions of most potentized homeopathic drugs, their efficacy in treating diseases is often put to question. However, our

For reprints and all correspondence: Anisur Rahman Khuda-Bukhsh, Department of Zoology, University of Kalyani, Kalyani-741235,

India. Tel: +91-33-25828750 extn. 315; Fax: +91-33-25828282;

E-mail: prof_arkb@yahoo.co.in; khudabukhsh_48@rediffmail.com recent works which showed the efficacy of certain homeopathic drugs in ameliorating p-dimethylaminoazobenzene (p-DAB) induced cancer in mice (11-14) have aroused interest in testing other homeopathic drugs for their possible anti-cancer effects. The azo dye p-DAB, used occasionally as a food additive, is known to act as initiator of liver cancer when used chronically (15-19) and is known to cause hazard to humans and animals (20-21). Phenobarbital (PB), predominantly used as an anti-epileptic/sedative drug, is known to have carcinogenic effect (22) to humans, mice and rats when administrated repeatedly (23-26). The effects are more pronounced when $\mathrm{PB}$ is used in combination with the azo-dye, which unfailingly produce liver tumors that

(C) 2007 The Author(s).

This is an Open Access article distributed under the terms of the Creative Commons Attribution Non-Commercial License (http://creativecommons.org/ licenses/by-nc/2.0/uk/) which permits unrestricted non-commercial use, distribution, and reproduction in any medium, provided the original work is properly cited. 
ultimately become neoplastic $(14,15,27)$. Therefore this induced liver carcinoma serves as a good model for the study of events during carcinogenesis as well as to test if a drug has any anti-cancerous effect. Further, homeopathic mode of treatment does not have any known side effects and is less expensive than that of conventional treatments of liver cancer which often needs surgery and costly medicines in management.

\section{Remedy Selection: Indication from a Pilot Study}

We have for some time been screening some homeopathic remedies, which are claimed to have pronounced effects in protecting liver from toxicity or that are known to help in recovery of liver dysfunction (e.g. Chelidonium, Lycopodium, etc.), for their possible anti-hepatotoxic/ anti-tumorigenic effects since the primary target organ of the carcinogens is the liver.

Potentized form of Natrum Sulphuricum is one such remedy generally used by homeopathic practitioners for various liver disorders having agreeable symptoms (28). As chronic feeding of $P-D A B$ and $\mathrm{PB}$ is known to cause symptoms arising out of liver disorders and Natrum Sulph being one of the remedies used to alleviate and protect liver from toxic effects, we first conducted a pilot study on the efficacy of Nat Sulph-30 with a limited number of protocols (data unpublished). On getting a positive result the present investigation was undertaken with a primary objective of evaluating efficacy of Nat Sulph-200 (a more diluted higher potency claimed to have stronger and longer lasting effect) in amelioration of carcinogen induced toxicity in mice utilizing several widely accepted protocols of cytogenetical and biochemical studies.

\section{Implications In Brief of the Parameters Used}

The parameters used in this study are important genotoxicity and cyto-toxicity (particularly hepatotoxin) biomarkers, either directly or indirectly implicated in the development of liver tumors. The changes observed in the cytogenetical studies led to the studies of LPO, which is associated with tissue damage and necrosis. Similarly, tissue damage and necrosis can lead to improper liver function and thereby causing hepato-toxicity. For this, liver function tests, that include the assay of various enzymes like AcP, AlkP, AST and ALT were selected to throw light on the extent of liver malfunctioning, if any. Further, if hepato-toxicity is generated, there will be generation of free radicals. GSH has anti-oxidant activity which is accomplished by scavenging free-radicals and the study of GSH was therefore of added value. Further, while decrease of the other biochemical parameters indicates decreased hepato-toxicity, a concomitant increase in GSH is expected to confirm this.

\section{Methods}

Feeding the Carcinogens and the Homeopathic Remedy to Mice

An inbred strain of Swiss albino mice (Mus musculus) were reared and maintained in the animal house of the Department of Zoology (with clearance from the University Ethical Committee and under the supervision of the Animal Welfare Committee), University of Kalyani, India, for the investigation. Mice under experiment were provided food and water and kept in a hygienic condition. The general diet was prepared from wheat, gram and powdered milk without any animal protein supplement. A group of 36 healthy mice weighing between 25-30 g were used for each treatment series, namely, (i) normal, (ii) normal+ alcohol 200 (iii) $P$-dimethylaminoazobenzene (p-DAB) + phenobarbital (PB), (iv) p-DAB + PB + alcohol 200, (v) $\mathrm{p}-D A B+\mathrm{PB}+\mathrm{Nat}$ Sulph-200 fed series. In our earlier studies, we used to maintain another group, only verum fed control along with normal+succussed alcohol fed control. But since the differences in data between these two series were negligible or insignificant, the normal+ verum fed group as control was later abandoned for saving life of mice and cost.

Each group of 36 mice divided into six different sets consisting of six mice each for six different intervals of fixation, namely, at day seven, 15, 30, 60, 90 and 120. The first set of mice (group-I, normal, negative control) was fed normal low protein diet. The second set of mice (group II) was fed diluted alcohol 200 (potentized as per homeopathic principle of dilution and succussion) with normal low protein diet. The third set of mice (group-III) was fed the same diet but mixed with $0.06 \%$ p-DAB (Sigma, D-6760) at a daily dose of $165 \mathrm{mg} / \mathrm{kg}$ body wt. per mouse $(15,27,29)$ and an oral dose of $0.06 \mathrm{ml}$ of $0.05 \%$ aqueous solution of PB daily $(14,30)$ through a specially made fine pipette. The fourth set of mice (group-IV, positive control) was fed $0.06 \%$ p-DAB along with $0.05 \%$ aqueous solution of $\mathrm{PB}$ as above and also diluted alcohol 200 (alc-200: as the 'vehicle' of the drug was ethyl alcohol), till they were sacrificed. The fifth set of mice (group-V) was fed p-DAB plus PB as in group-III, but was also fed Nat Sulph-200 once a day till they were sacrificed at day seven, 15, 30, 60, 90 and 120 .

\section{Feeding Procedure and Dose}

Each mouse was fed one drop $(0.06 \mathrm{ml})$ of stock solution of Nat Sulph-200 or alc-200, as the case may be, once daily (one dose at 7 A.M) with the aid of a fine pipette. 


\section{Preparation of the Potentized Form of the Drug}

The potentized homeopathic drug, Nat Sulph-200, was procured from 'HAPCO', 165, Bipin Behari Ganguly Street, Kolkata, India. The 200 potency of Natrum Sulph was derived from the mother tincture of sodium sulphate by 'succussion and dilution' procedure $(31,32)$ as recommended in the Homeopathic Pharmacopoeia of India, Vol. I (33). The glass vial containing potentized alc-200 provided by 'HAPCO' having been accidentally broken during the initial days of experiment, the available 'placebo' provided by Boiron Lab, Lyon, France, had been used. However, we examined various physical properties of both the 'placebos' prepared by 'HAPCO' and 'BOIRON' through UV, FTIR, fluorescence, 13 C-NMR and 1H-NMR spectroscopy earlier (34) but failed to observe any significant difference between the two 'placebos'.

\section{Laboratory Methodology}

\section{Cytogenetic Assay}

The standard and widely practiced cytogenetic protocols like assays of chromosome aberration (CA), micronuclei $(\mathrm{MN})$, mitotic index (MI) and sperm head anomaly (SHA) have been adopted in the present study for testing genotoxicity $(14,26)$. A total of 300 bone marrow cells were observed for CA, 3000 cells for MN and 5000 cells for MI and 5000 sperm for SHA analysis.

\section{Biochemical Assays}

After collection of blood by ventricular puncture from etherized mice (approx $1.5 \mathrm{ml}$ from each mouse), they were sacrificed and their liver and spleen were quickly collected in an ice tray.

For the study of aspartate and alanine amino transferases (AST and ALT, respectively), acid and alkaline phosphatases (AcP and AlkP, respectively) and lipid peroxidation (LPO) and reduced glutathione content (GSH) standard methods (14) were adopted.

\section{Statistical Analysis}

The significance of difference between data of the different series was conducted by Student's $t$-test and two-way ANOVA (Mini Tab 13.01) was performed. This experiment was done as per randomized double blind placebo control method.

\section{Results}

\section{Tumor Growth}

Out of 18 mice sacrificed at three longer fixation intervals (i.e. at day 60, 90 and 120), 15 and 16 mice, respectively, showed liver tumors in the p-DAB $+\mathrm{PB}$ fed and $\mathrm{p}-D A B+\mathrm{PB}+$ alc-200 fed series, while altogether eight mice showed liver tumors in the drug fed series (Table 1). The tumors looked pale reddish in color. Some of them were present as solitary or a few individually distinguishable ones (mostly in drug fed mice) much less in magnitude than the multiple innumerable nodules (mostly in drug unfed mice), which were considered as true tumors and the one or two nodules present in a few were ignored. On this estimate, Nat Sulph-200 fed mice showed an overall protection to the tune of $41.7 \%$ (Nat Sulph-30 rendered $31.1 \%$, unpublished data) when data of all three longer intervals of fixation were considered.

\section{Cytogenetical Studies}

As compared with normal metaphase plate (Fig.1A), there was a palpable increase in the frequencies of various types of CA (Fig. 1B-D) in different treatment series during all fixation periods. Several types of chromosome aberrations - both of major and minor types - were observed in certain metaphase plates of $\mathrm{p}-D A B+\mathrm{PB}$ and $\mathrm{p}-\mathrm{DAB}+\mathrm{PB}+$ alc-200 fed mice. The total frequencies of aberrations were maximum in $\mathrm{p}-D A B+\mathrm{PB}+$ alc-200 fed mice. The frequency of $\mathrm{CA}$ was always greater in $\mathrm{p}-\mathrm{DAB}+\mathrm{PB}$ fed mice than in normal (Gr. I) and normal + alc-200 fed (Gr. II) mice.

Table 1. Number of animals showing tumors at different fixation intervals after chronic feeding of p-DAB plus PB for 7, 15, $30,60,90$ and 120 days, in each fixation intervals 6 mice each were used per set

\begin{tabular}{|c|c|c|c|c|c|c|c|}
\hline Series & $\begin{array}{l}\text { No. of } \\
\text { specimens } \\
\text { used }\end{array}$ & $\begin{array}{l}\text { Tumor } \\
\text { incidence } \\
7 \text { days }\end{array}$ & $\begin{array}{l}\text { Tumor } \\
\text { incidence } \\
15 \text { days }\end{array}$ & $\begin{array}{l}\text { Tumor } \\
\text { incidence } \\
30 \text { days }\end{array}$ & $\begin{array}{l}\text { Tumor } \\
\text { incidence } \\
60 \text { days }\end{array}$ & $\begin{array}{l}\text { Tumor } \\
\text { incidence } \\
90 \text { days }\end{array}$ & $\begin{array}{l}\text { Tumor } \\
\text { incidence } \\
120 \text { days }\end{array}$ \\
\hline Normal & 36 & $0 / 6$ & $0 / 6$ & $0 / 6$ & $0 / 6$ & $0 / 6$ & $0 / 6$ \\
\hline $\mathrm{p}-\mathrm{DAB}+\mathrm{PB}$ & 36 & $0 / 6$ & $0 / 6$ & $0 / 6$ & $3 / 6$ & $6 / 6$ & $6 / 6$ \\
\hline $\mathrm{p}-\mathrm{DAB}+\mathrm{PB}+\mathrm{Alc}-200$ & 36 & $0 / 6$ & $0 / 6$ & $0 / 6$ & $4 / 6$ & $6 / 6$ & $6 / 6$ \\
\hline
\end{tabular}




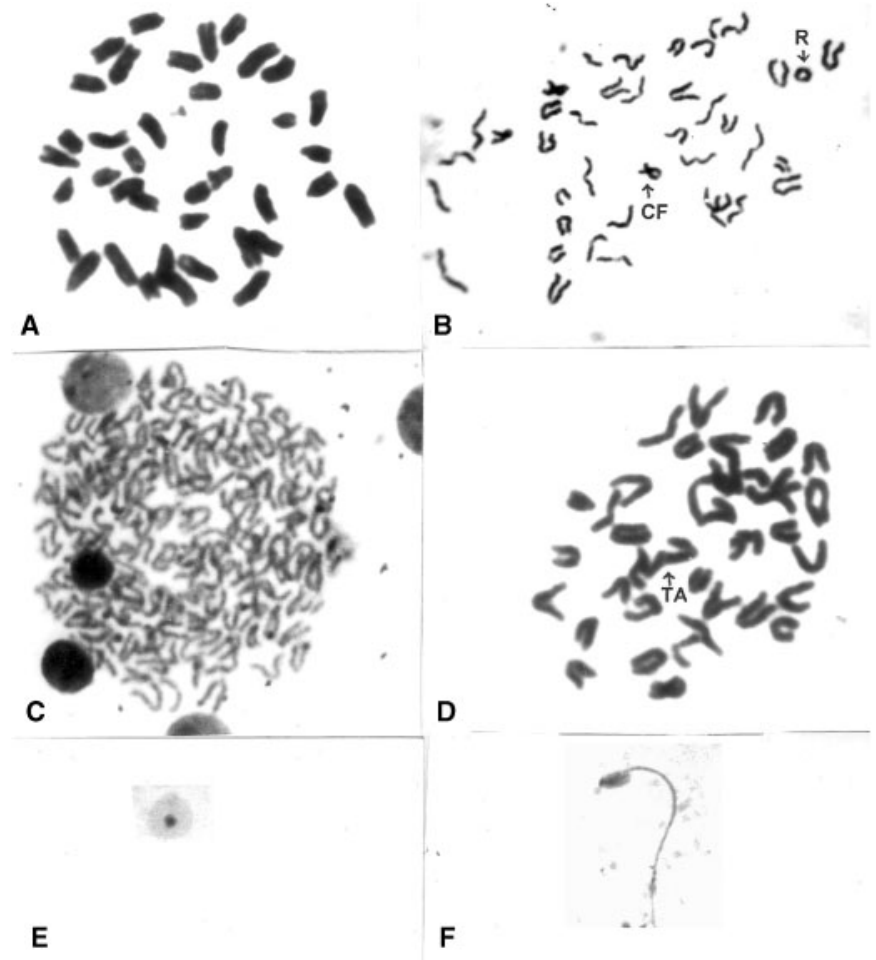

Figure 1. (A-F). (A) Photomicrographs of normal metaphase complement, (B): Ring (R) and Centric fusion (CF), (C): Polyploidy, (D): Terminal association (TA), (E): Erythrocyte showing micronucleus; (F): Sperm with abnormal head shape.

The frequency of CA in p-DAB $+\mathrm{PB}+$ Nat Sulph-200 fed group was found to be considerably decreased $(P<0.01-P<0.001)$ at all fixation intervals except at day seven (Fig. 2A).

\section{Micronucleated Erythrocytes}

The incidence of micronuclei (Fig. 1E; which represent a fragment or broken part or whole arm of a chromosome), in carcinogen fed as also p-DAB $+\mathrm{PB}+$ alc- 200 fed mice was appreciably higher than that of normal control mice at all fixation intervals. However, there was a palpable decrease in $\mathrm{MN}$ in the drug fed series $(P<0.05-P<0.001)$. The decrease was a result of reduction in number of both polychromatic (PCE) and normochromatic (NCE) erythrocytes (Fig. 2B).

\section{Mitotic Index}

The mitotic indices represent the rate at which the cells pass through a cell cycle. When a cell becomes transformed into a tumor cell, the rate becomes increased for failure of proper control of cell division and thus may be used as an indicator of tumorigenicity. The mitotic indices of mice fed either $p-D A B+P B$ or $\mathrm{p}-\mathrm{DAB}+\mathrm{PB}+\mathrm{Alc}-200$ were higher than that of the normal control series. In $\mathrm{p}-\mathrm{DAB}+\mathrm{PB}+\mathrm{Nat}$
Sulph-200 fed mice, there was a significant decrease $(P<0.05-P<0.001)$ in $\mathrm{MI}$ at all fixation intervals except at day seven (Fig. 2C).

\section{Sperm Head Anomaly}

Genotoxic or carcinogenic or spermatotoxic agents can cause damage to sperm head, which may be an indicator of the risk of transmission of mutagenic trait, if these deformed sperm by chance fertilize the ovum. Greater number of sperm with abnormal head morphologies (Fig. 1G) was encountered in $\mathrm{p}-\mathrm{DAB}+\mathrm{PB}$ fed and $\mathrm{p}-D A B+\mathrm{PB}+$ alc-200 fed mice at all fixation intervals. The frequencies of SHA were considerably decreased in p-DAB $+\mathrm{PB}+\mathrm{Nat}$ Sulph-200 fed group at all fixation intervals $(P<0.05-P<0.001)$ (Fig. 2D) except at day 7 .

\section{Biochemical Assay}

\section{Aspartate Amino Transferase Activity (AST)}

The AST activity in liver was increased in both $\mathrm{p}-D A B+\mathrm{PB}$ fed and $\mathrm{p}-\mathrm{DAB}+\mathrm{PB}+\mathrm{Alc}-200$ fed mice at all fixation intervals. However, the AST activity in p-DAB+PB + Nat Sulph-200 fed series appeared to decrease significantly $(P<0.01-P<0.001)$ from day 15 - day 120 (Table 2) in liver.

\section{Alanine Amino Transferase Activity (ALT)}

Similar trend of reduction in ALT activity $(P<0.01-$ $P<0.001)$ was noticed in liver of the $\mathrm{p}-\mathrm{Dab}+\mathrm{PB}+\mathrm{Nat}$ Sulph-200 fed mice when compared to that of $\mathrm{p}-\mathrm{Dab}+\mathrm{PB}+\mathrm{Alc}-200$ fed mice at all fixation intervals except at day seven (Table 3).

\section{Acid Phosphatase Activity (AcP)}

The activity of AcP in liver showed a trend of steady rise from day 7 to day 15 in p-Dab + PB fed mice, then decreased at day 60 and 90, only to rise again at day 120 . The same trend was noticed in the p-Dab + PB + Alc-200 fed series. The activity of AcP was decreased significantly $(P<0.01)$ (Table 4$)$ in the drug fed mice at all fixation intervals except at day 7 .

\section{Alkaline Phosphatase Activity (AlkP)}

The activity of AlkP was enhanced in liver of p-Dab + PB fed mice from day seven through day 120 and the same in p-Dab + PB + Nat Sulph-200 fed mice decreased appreciably $(P<0.05$ through $P<0.001)$ at all fixation intervals (Table 5).

\section{Lipid Peroxidation (LPO)}

Lipid peroxidation was considerably higher in p-Dab + $\mathrm{PB}+$ Alc-200 fed mice. However, there was a significant 
Histograms showing \% of CA of different series at different days interval

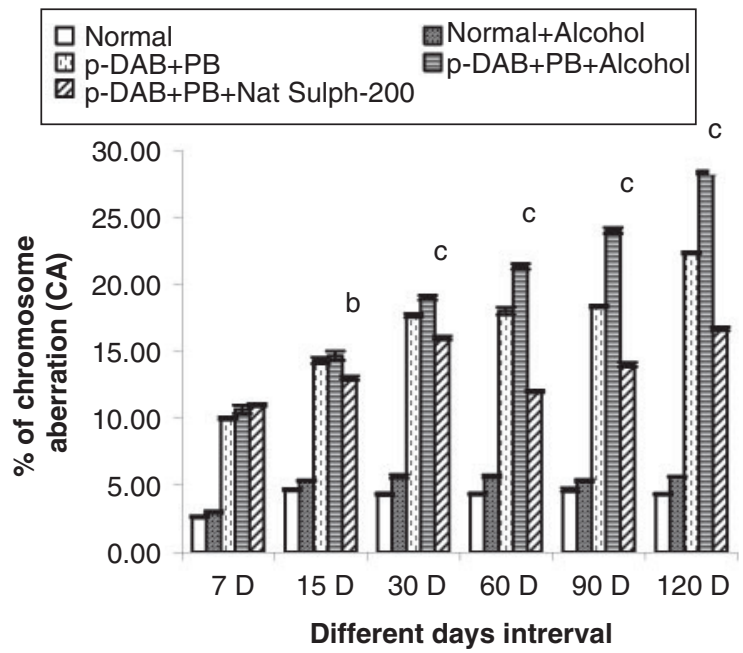

A

Histograms showing \% of MI of different series at different days interval

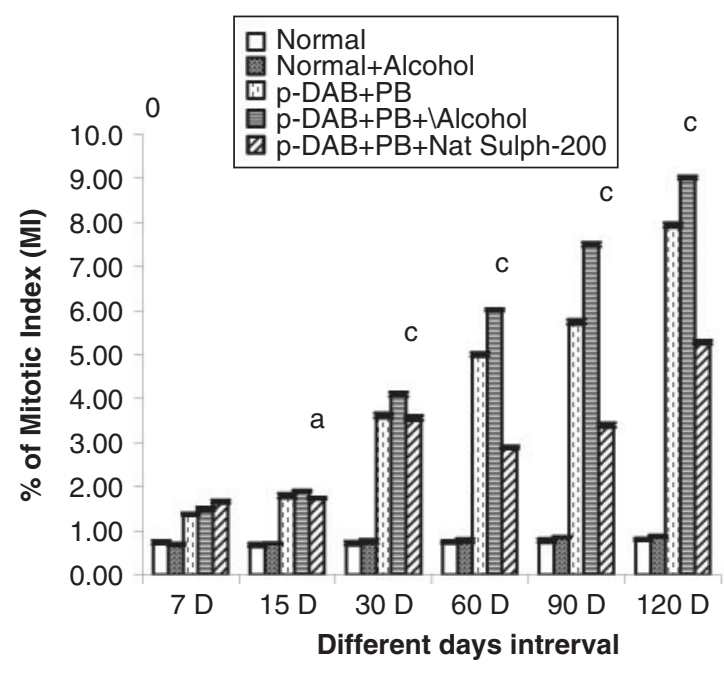

C
Histograms showing \% of MNE of different series at different days interval

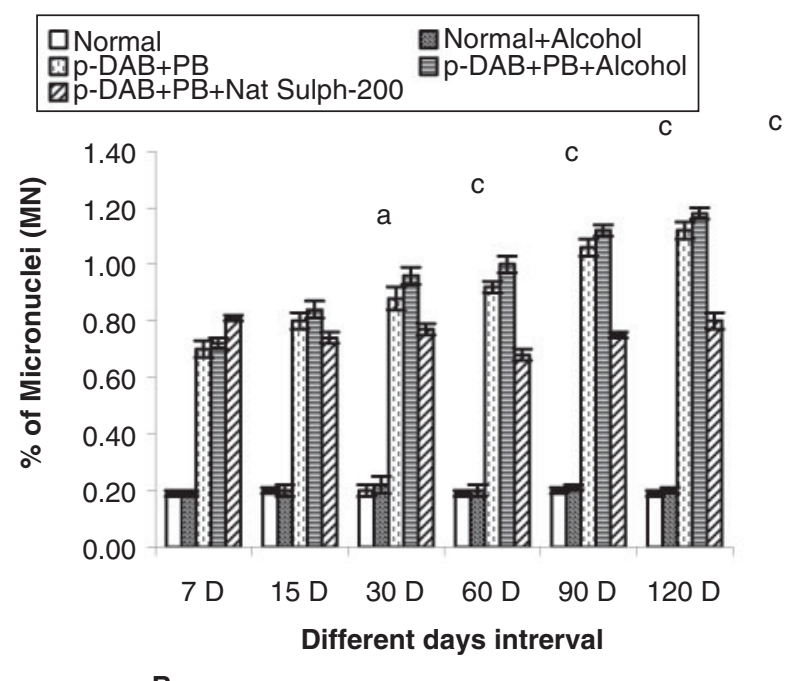

Histograms showing $\%$ of SHA of differnt series at different days interval

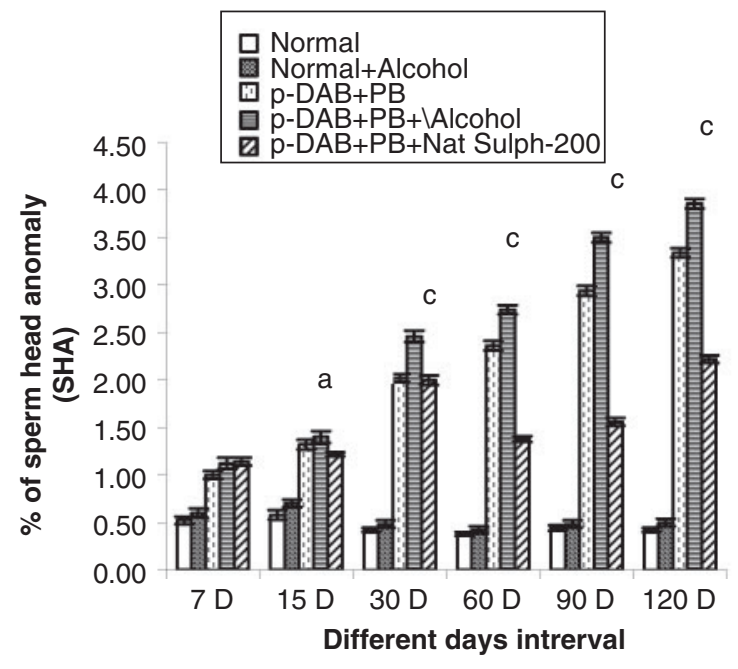

D

Figure 2. (A-D). Histograms showing the following: (A) percentage (\%) of chromosomal aberrations (CA) in different series of mice at different fixation intervals; (B) percentage (\%) of micronucleated erythrocytes (MN) in different series of mice at different fixation intervals; (C) percentage $(\%)$ of mitotic indices in different series of mice at different fixation intervals; and (D) percentage (\%) of sperm head anomalies (SHA) in different series of mice at different fixation intervals. Statistical analyses were done between series p-DAB $+\mathrm{PB}+\mathrm{Alcohol}-200$ versus $\mathrm{p}-\mathrm{DAB}+\mathrm{PB}+\mathrm{Nat}$ Sulph-200. The different levels of statistical significances between two given series have been designated by $* P<0.05, * * P<0.01, * * * P<0.001$. p-DAB, p-dimethylaminoazobenzene; PB, phenobarbital; Nat Sulph-200, Natrum Sulphuricum-200.

decrease $(P<0.05$ through $P<0.001)$ in lipid peroxidation in liver of $\mathrm{p}-\mathrm{Dab}+\mathrm{PB}+\mathrm{Nat}$ Sulph-200 fed mice at all fixation intervals (Table 6).

\section{Reduced Glutathione Content (GSH)}

The reduced glutathione content decreased in $\mathrm{p}-\mathrm{Dab}+$ $\mathrm{PB}+$ Alc-200 fed mice at all fixation intervals. However, there was an increase in reduced glutathione content of
p-Dab + PB + Nat Sulph-200 fed mice at all fixation intervals $(P<0.05$ to $P<0.01)$ (Table 7$)$ in liver.

\section{Results of Statistical Analysis}

The significance of differences between data of the different series was determined by Student's $t$-test and the results of two-way ANOVA (Mini Tab 13.01) are summarized in Tables 2-7 and Table 8-9. 
Table 2. Mean Aspartate amino transferase (AST) activity in $(\mathrm{nM} / 100 \mathrm{mg}$ protein/ Min) in liver of mice treated with $\mathrm{p}-\mathrm{DAB}+\mathrm{PB}$, p-DAB + PB + alc-200, p-DAB + PB + Nat Sulph-200, normal and negative controls at different fixation intervals. The different levels of statistical significances between two given series have been designated by *,**,***

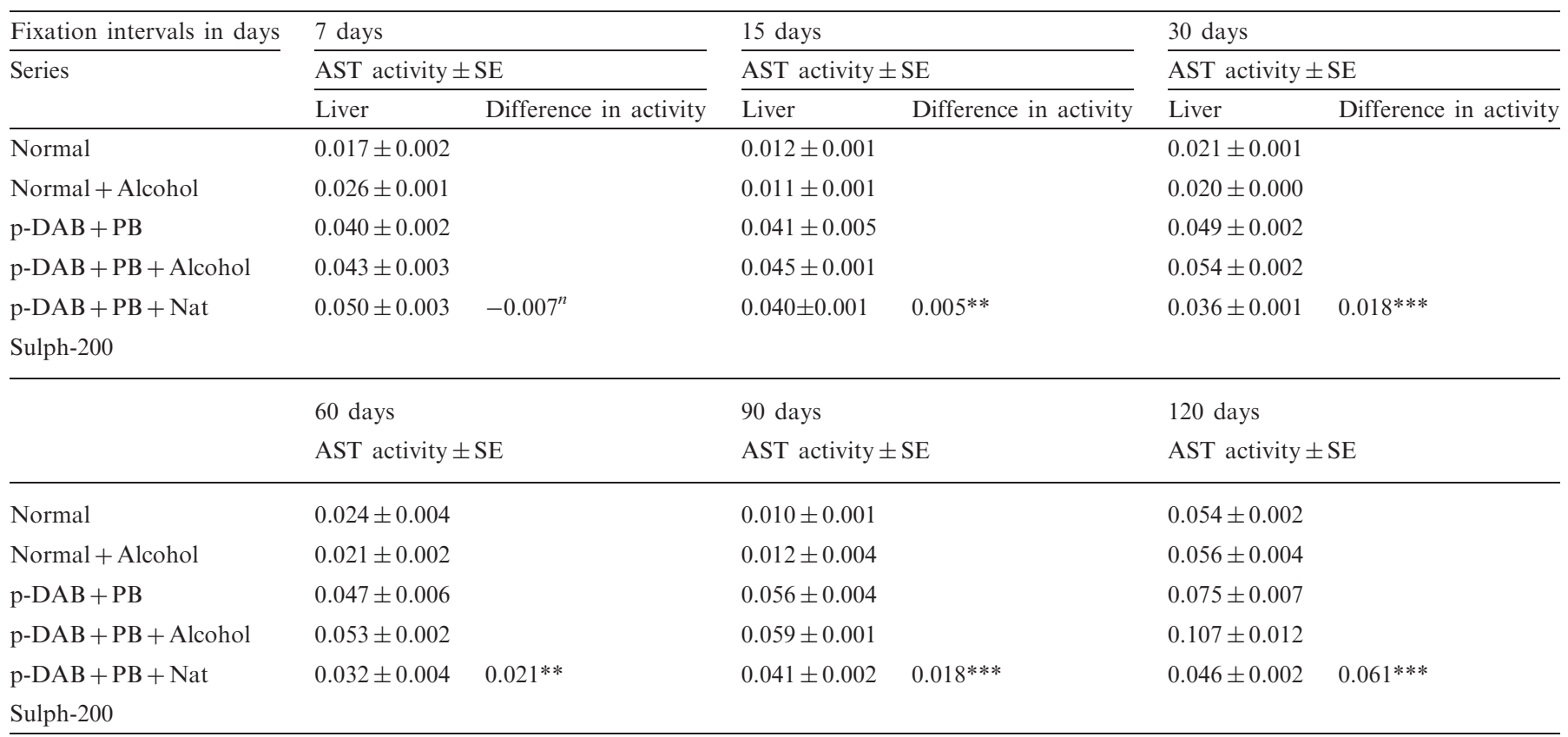

$* P<0.05, * * P<0.01, * * * P<0.001, n=$ non-significant.

Statistical analyses were done between series p-DAB $+\mathrm{PB}+$ Alcohol versus p-DAB $+\mathrm{PB}+\mathrm{Nat}$ Sulph-200.

p-DAB, p-dimethylaminoazobenzene; PB, phenobarbital; Nat Sulph-200, Natrum Sulphuricum-200; SE, standard error.

Table 3. Mean Alanine amino transferase (ALT) activity in $(\mathrm{nM} / 100 \mathrm{mg}$ protein/ Min) in liver of mice treated with $\mathrm{p}-\mathrm{DAB}+\mathrm{PB}, \mathrm{p}-\mathrm{DAB}+\mathrm{PB}+$ alc-200, p-DAB + PB + Nat Sulph-200, normal and negative controls at different fixation intervals. The different levels of statistical significances between two given series have been designated by $*, * *, * * *$

\begin{tabular}{|c|c|c|c|c|c|c|}
\hline \multirow{3}{*}{$\frac{\text { Fixation intervals in days }}{\text { Series }}$} & \multicolumn{2}{|l|}{7 days } & \multicolumn{2}{|l|}{15 days } & \multicolumn{2}{|l|}{30 days } \\
\hline & \multicolumn{2}{|c|}{$\mathrm{ALT}$ activity $\pm \mathrm{SE}$} & \multicolumn{2}{|c|}{$\mathrm{ALT}$ activity $\pm \mathrm{SE}$} & \multicolumn{2}{|c|}{$\mathrm{ALT}$ activity $\pm \mathrm{SE}$} \\
\hline & Liver & Difference in activity & Liver & Difference in activity & Liver & Difference in activity \\
\hline Normal & $0.006 \pm 0.000$ & & $0.010 \pm 0.001$ & & $0.005 \pm 0.000$ & \\
\hline Normal + Alcohol & $0.011 \pm 0.001$ & & $0.012 \pm 0.001$ & & $0.009 \pm 0.001$ & \\
\hline $\mathrm{p}-\mathrm{DAB}+\mathrm{PB}$ & $0.009 \pm 0.002$ & & $0.028 \pm 0.002$ & & $0.017 \pm 0.002$ & \\
\hline p-DAB + PB + Alcohol & $0.014 \pm 0.001$ & & $0.036 \pm 0.002$ & & $0.022 \pm 0.001$ & \\
\hline
\end{tabular}

\begin{tabular}{|c|c|c|c|}
\hline Normal + Alcohol & $0.007 \pm 0.001$ & $0.006 \pm 0.001$ & $0.005 \pm 0.001$ \\
\hline $\mathrm{p}-\mathrm{DAB}+\mathrm{PB}$ & $0.015 \pm 0.001$ & $0.015 \pm 0.002$ & $0.019 \pm 0.001$ \\
\hline $\mathrm{p}-\mathrm{DAB}+\mathrm{PB}+$ Alcohol & $0.024 \pm 0.001$ & $0.017 \pm 0.002$ & $0.020 \pm 0.002$ \\
\hline
\end{tabular}

$* P<0.05, * * P<0.01, * * * P<0.001, n=$ non-significant.

Statistical analyses were done between series p-DAB $+\mathrm{PB}+$ Alcohol versus p-DAB + PB + Nat Sulph-200.

p-DAB, p-dimethylaminoazobenzene; PB, phenobarbital; Nat Sulph-200, Natrum Sulphuricum-200; SE, standard error. 
Table 4. Mean Acid phosphatase (AcP) activity in $(\mathrm{nM} / 100 \mathrm{mg}$ protein/ Min) in liver of mice treated with $\mathrm{p}-\mathrm{DAB}+\mathrm{PB}, \mathrm{p}-\mathrm{DAB}+\mathrm{PB}+\mathrm{alc}-200$, p-DAB + PB + Nat Sulph-200, normal and negative controls at different fixation intervals. The different levels of statistical significances between two given series have been designated by $*, * *, * * *$

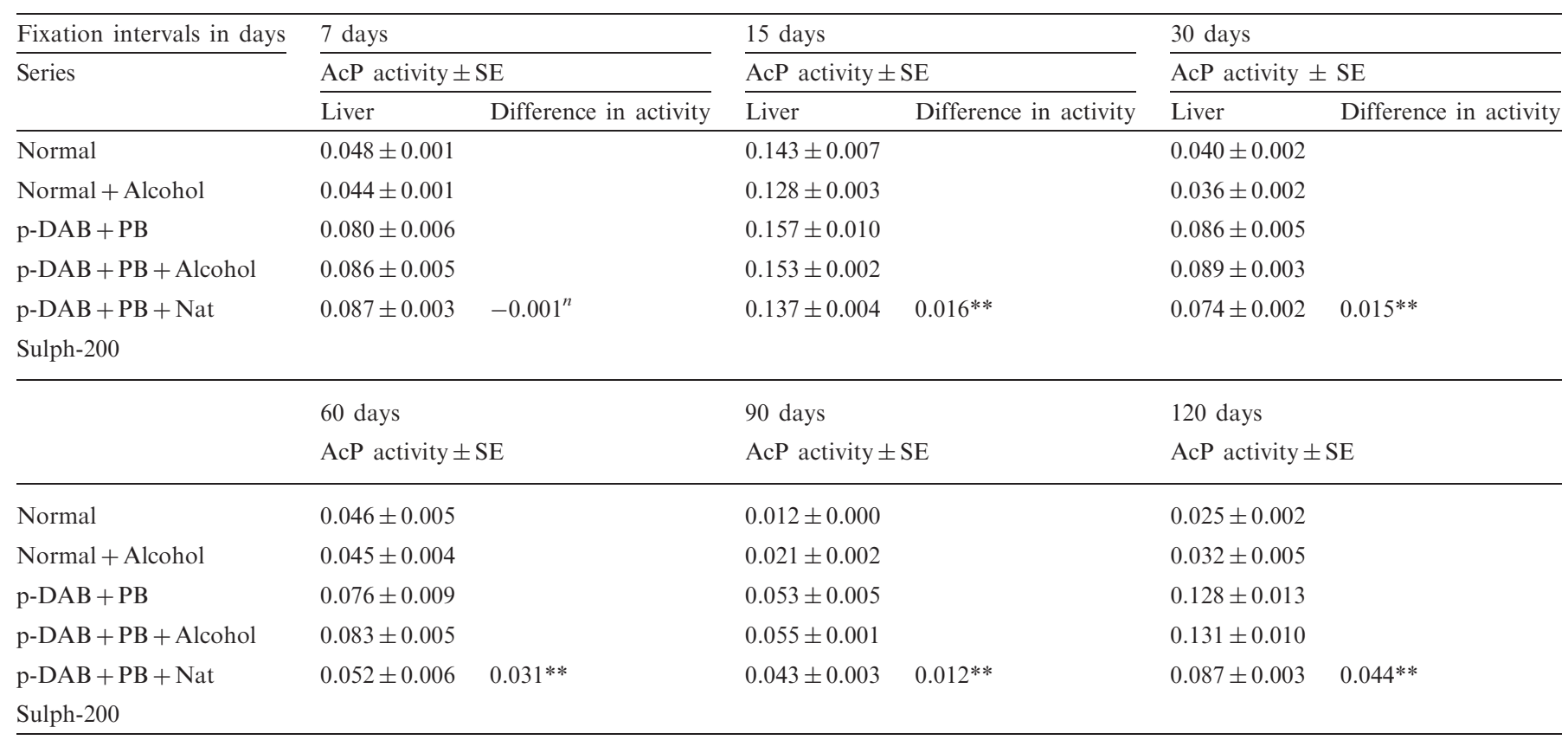

$* P<0.05, * * P<0.01, * * * P<0.001, n=$ non-significant

Statistical analyses were done between series p-DAB $+\mathrm{PB}+$ Alcohol versus p-DAB $+\mathrm{PB}+\mathrm{Nat}$ Sulph-200.

p-DAB, p-dimethylaminoazobenzene; PB, phenobarbital; Nat Sulph-200, Natrum Sulphuricum-200; SE, standard error.

Table 5. Mean Alkaline phosphatase (AlkP) activity in $(\mathrm{nM} / 100 \mathrm{mg}$ protein/ Min) in liver of mice treated with $\mathrm{p}-\mathrm{DAB}+\mathrm{PB}, \mathrm{p}-\mathrm{DAB}+\mathrm{PB}+$ alc-200, p-DAB + PB + Nat Sulph-200, normal and negative controls at different fixation intervals. The different levels of statistical significances between two given series have been designated by $*, * *, * *$

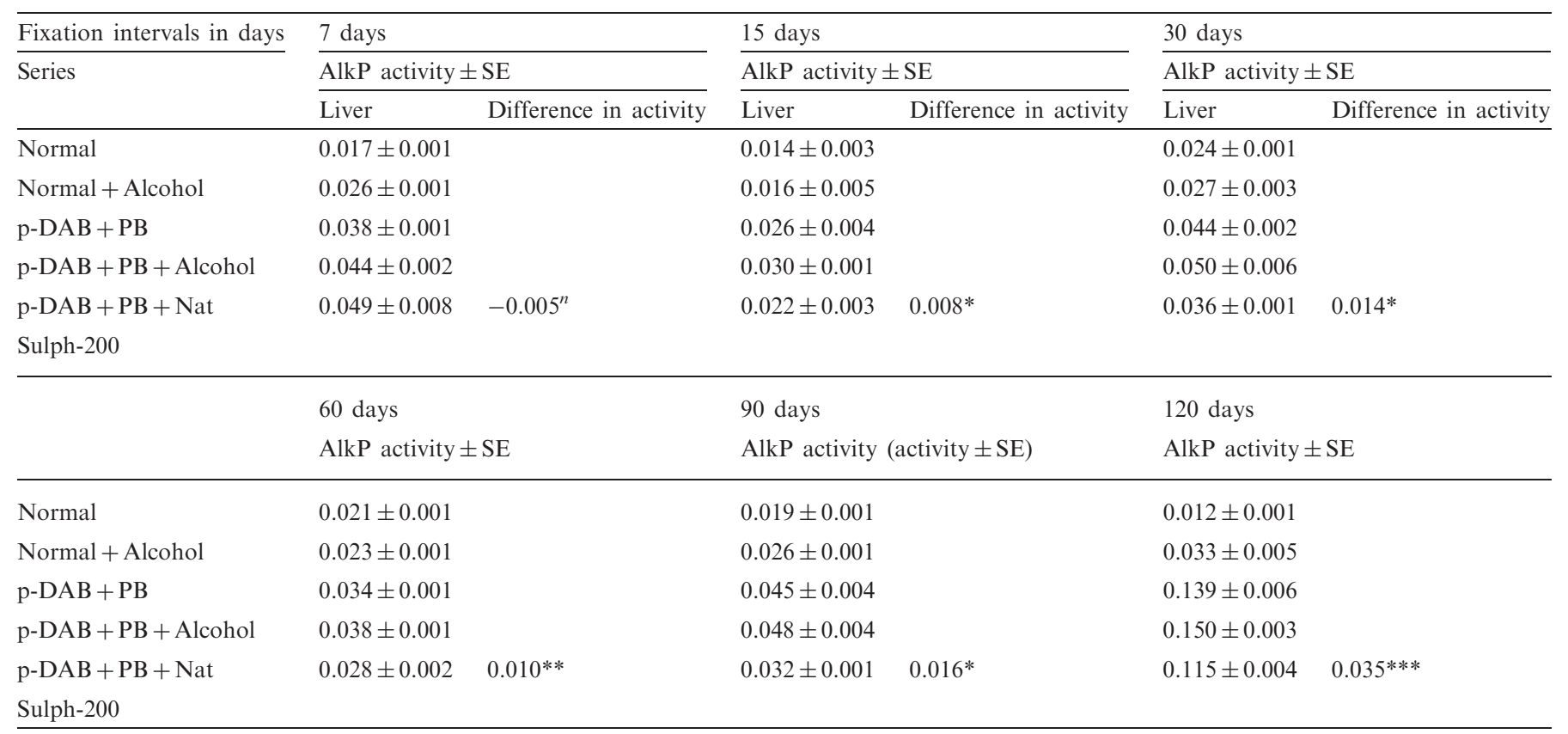

$* P<0.05, * * P<0.01, * * * P<0.001, n=$ non-significant.

Statistical analyses were done between series p-DAB + PB + Alcohol versus p-DAB + PB + Nat Sulph-200.

p-DAB, p-dimethylaminoazobenzene; PB, phenobarbital; Nat Sulph-200, Natrum Sulphuricum-200; SE, standard error. 
Table 6. Mean Lipid peroxidation (LPO) activity in ( $\mathrm{nM} / \mathrm{MDA} / \mathrm{mg}$ wet tissue) in liver of mice treated with $\mathrm{p}-\mathrm{DAB}+\mathrm{PB}, \mathrm{p}-\mathrm{DAB}+\mathrm{PB}+$ alc-200, p-DAB $+\mathrm{PB}+\mathrm{Nat}$ Sulph-200, normal and negative controls at different fixation intervals. The different levels of statistical significances between two given series have been designated by *,**,***

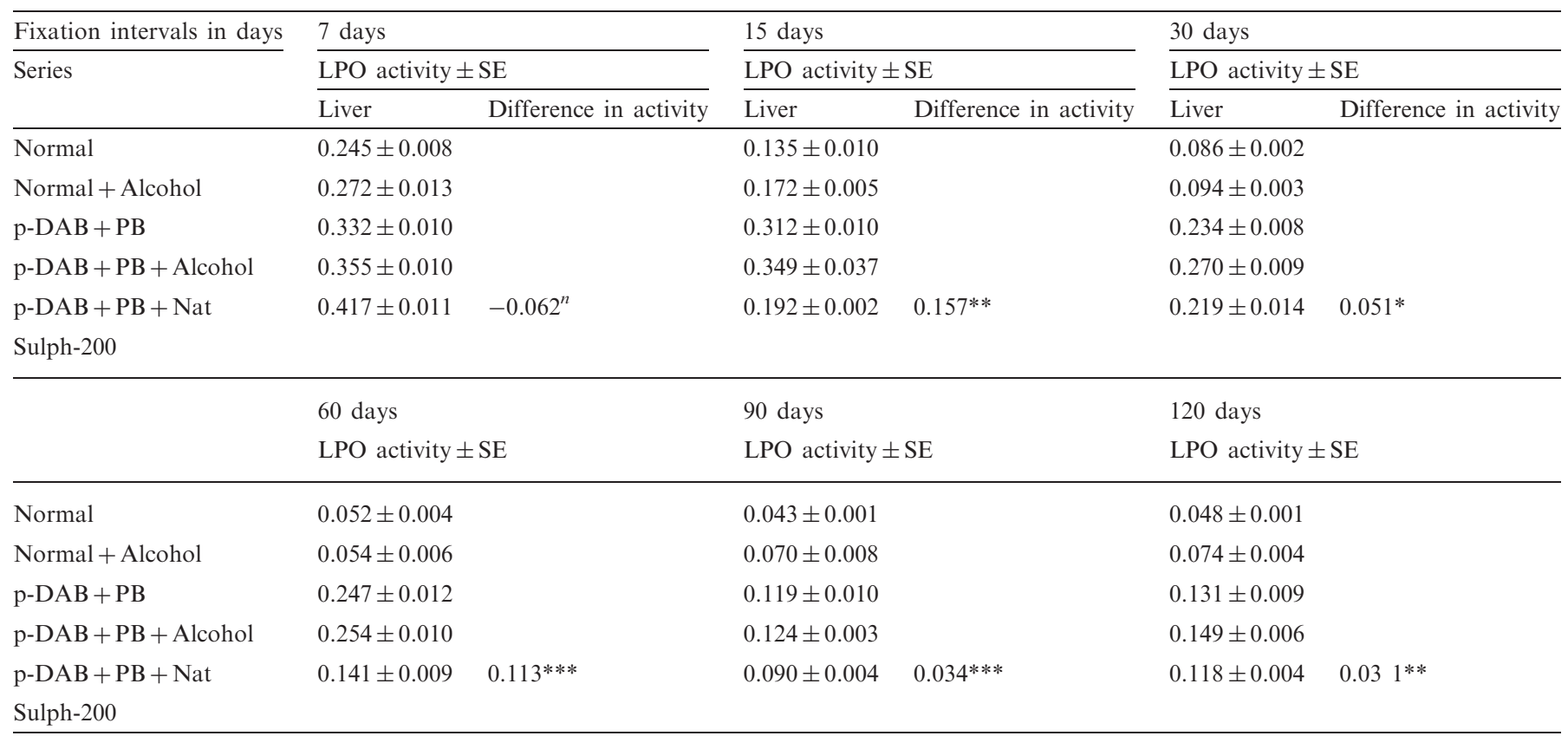

$* P<0.05, * * P<0.01, * * * P<0.001, n=$ non-significant.

Statistical analyses were done between series p-DAB $+\mathrm{PB}+$ Alcohol versus p-DAB $+\mathrm{PB}+\mathrm{Nat}$ Sulph-200.

p-DAB, p-dimethylaminoazobenzene; PB, phenobarbital; Nat Sulph-200, Natrum Sulphuricum-200; SE, standard error.

Table 7. Mean Reduced glutathione (GSH) content in (nM/mg wet tissue) in liver of mice treated with $\mathrm{p}-\mathrm{DAB}+\mathrm{PB}, \mathrm{p}-\mathrm{DAB}+\mathrm{PB}+\mathrm{alc}-200$, $\mathrm{p}-\mathrm{DAB}+\mathrm{PB}+\mathrm{Nat}$ Sulph-200, normal and negative controls at different fixation intervals. The different levels of statistical significances between two given series have been designated by $*, * *, * * *$

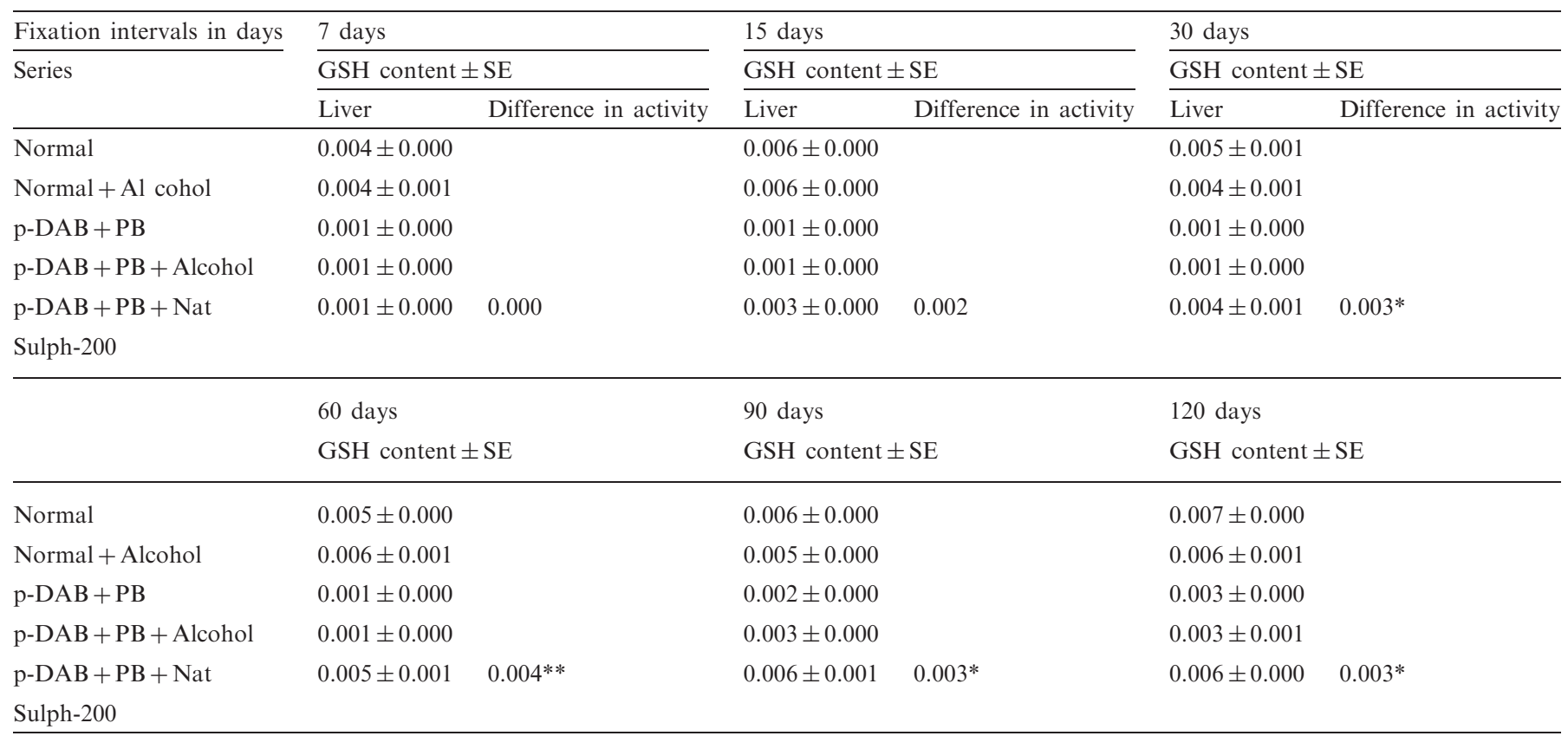

$* P<0.05, * * P<0.01, * * * P<0.001, n=$ non-significant.

Statistical analyses were done between series $\mathrm{p}-\mathrm{DAB}+\mathrm{PB}+$ Alcohol versus p-DAB $+\mathrm{PB}+\mathrm{Nat}$ Sulph-200.

p-DAB, p-dimethylaminoazobenzene; PB, phenobarbital; Nat Sulph-200, Natrum Sulphuricum-200; SE, standard error. 
Table 8. Showing two-way ANOVA analyses for different cytogenetical parameters

\begin{tabular}{|c|c|c|c|c|c|c|c|c|c|}
\hline \multirow{2}{*}{$\begin{array}{l}\text { Two way ANOVA } \\
\text { Source of Variation }\end{array}$} & \multicolumn{3}{|c|}{ Mitotic index } & \multicolumn{2}{|c|}{ Chromosome Aberration } & \multicolumn{2}{|c|}{ Micro nucleated Erythrocytes } & \multicolumn{2}{|c|}{ Sperm Head Anomaly } \\
\hline & $\mathrm{df}$ & MS & $\mathrm{F}$ & MS & $\mathrm{F}$ & MS & $\mathrm{F}$ & MS & $\mathrm{F}$ \\
\hline Dues to Series & 4 & 23.26 & $11.23^{*}$ & 289.13 & $39.45^{*}$ & 0.8247 & $95.82 *$ & 5.26 & $15.02 *$ \\
\hline
\end{tabular}

$* P<0.05$

Table 9. Showing two-way ANOVA analyses for different enzymatic parameters

\begin{tabular}{|c|c|c|c|c|c|c|c|c|c|c|c|c|c|}
\hline \multirow{2}{*}{$\frac{\text { Two way ANOVA }}{\text { Source of Variation }}$} & \multicolumn{3}{|c|}{ AST activity } & \multicolumn{2}{|c|}{ ALT activity } & \multicolumn{2}{|c|}{ AcP activity } & \multicolumn{2}{|c|}{ AlkP activity } & \multicolumn{2}{|c|}{ LPO activity } & \multicolumn{2}{|c|}{ GSH content } \\
\hline & $\overline{\mathrm{df}}$ & MS & $\mathrm{F}$ & MS & $\mathrm{F}$ & MS & $\mathrm{F}$ & $\overline{\mathrm{MS}}$ & $\mathrm{F}$ & MS & $\mathrm{F}$ & $\overline{\mathrm{MS}}$ & $\mathrm{F}$ \\
\hline Dues to Series & 4 & 0.0016054 & $17.90^{*}$ & 0.0002548 & 14.12 & 0.003271 & 13.39 & 0.002043 & 4.10 & $0.02558 *$ & 16.78 & 0.0000218 & 33.03 \\
\hline
\end{tabular}

$* P<0.05$

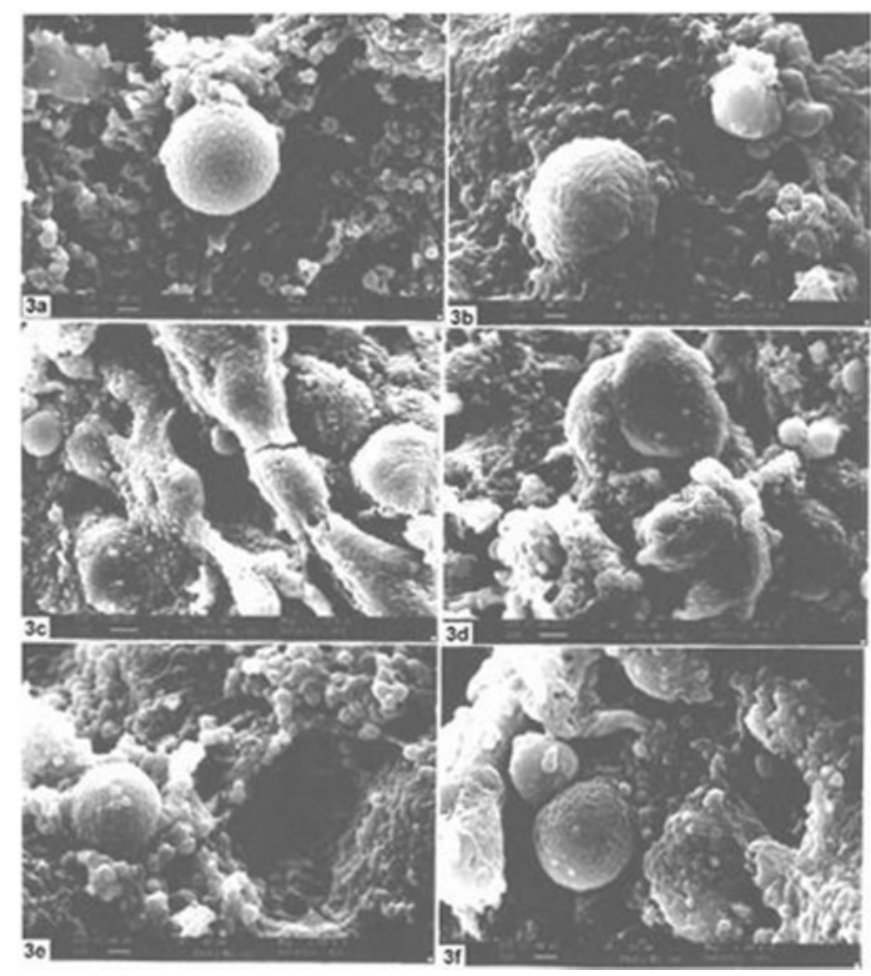

Figure 3. Section of liver under SEM: showing features of normal $(3 \mathrm{a}-3 \mathrm{~b}), \mathrm{p}-\mathrm{DAB}+\mathrm{PB}+$ Alcohol fed (3c-3d) and $\mathrm{p}-\mathrm{DAB}+\mathrm{PB}+\mathrm{Nat}$ Sulph-200 fed mice (3c-3f).

\section{Discussion}

In the present study, several widely accepted toxicity markers have been used, all of which are known to have significant role during the carcinogenesis process (14,35-44). In brief, the significant reduction of biomarkers like AST, ALT, AcP, AlkP and LPO and increase of GSH in the drug fed series speak for the reduction of hepato-toxicity and injury $(14,35)$. Positive modulations

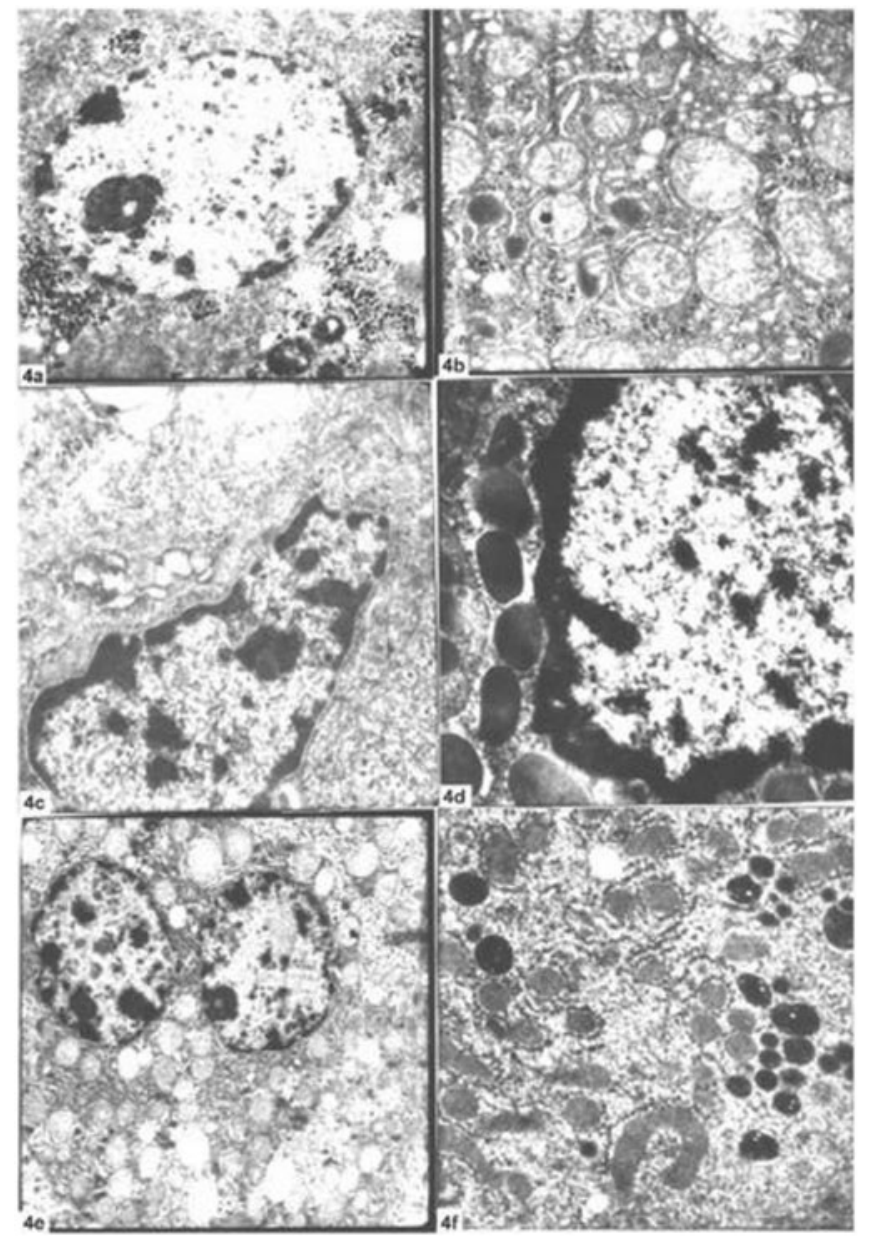

Figure 4. Liver section under TEM: showing features of normal (4a-4b). $\mathrm{p}-\mathrm{DAB}+\mathrm{PB}+$ Alcohol fed $(4 \mathrm{c}-4 \mathrm{~d})$ and $\mathrm{p}-\mathrm{DAB}+\mathrm{PB}+\mathrm{Nat}$ sulph-200 fed mice $(4 c-4 d)$.

of several other parameters, such as, blood glucose, cholesterol, testosterone and estradiol were also noted (data not shown). Similarly, there were evidences from electron microscopic studies (both scanning, Fig. 3; and 
transmission, Fig. 4) on liver that the homeopathic remedy played a positive role in protecting ultrastructural integrities (data not shown). Incidentally, reactive oxygen species (ROS) are produced by metabolism of various endogenous and exogenous compounds and are associated in the pathogenesis of different liver diseases, such as cirrhosis and hepatocellular cancer (4144). In cirrhosis and hepatocellular carcinoma, the antioxidant system is damaged severely and the GSH level falls down, the MDA level rises and GSHdependent enzyme activities are enhanced in cirrhotic and cancer tissues (43). Incidentally, positive effects of homeopathic preparations on human prostate cancer growth have recently been studied by Maclaughlin et al. (45) and Jonas et al., (46) while crude extracts of some plants have also been shown to have anti-cancerous activities against prostate cancer cell line in human (47) and in skin carcinogenesis (48) and leukemia and aging (49) of mice.

In recent years, cell death in brain cancer has been observed by some workers (50) by administering a homeopathic drug, Ruta 6, both on in vivo and in vitro systems. But how the micro doses of the highly diluted homeopathic remedy could bring about such positive changes in diverse parameters of study is not yet properly understood. The ability of the homeopathic remedy in bringing down cytogenetical damage along with the positive biochemical changes can be considered as proofs of their ability towards restoring normalcy in the functioning of body's important metabolic enzymes and mechanism of repair and retrieval for genome, presumably by activating/deactivating the relevant genes responsible for regulation of their respective activities $(51,31,32)$.

\section{Conclusions}

Finally, compared with Nat Sulph-30, Nat Sulph-200 appeared to show a little better efficacy in reducing the incidence of tumors in liver, and most other common parameters tested with both potencies, particularly at some longer intervals of fixation. Therefore, other researchers are encouraged to replicate the study in mice and/or other mammalian models and see if potentized remedies of Natrum Sulphuricum can be recommended as a potential supportive medicine for use in human cancer therapy as well.

\section{Acknowledgements}

This work was financially supported by an EMR grant of AYUSH, Ministry of Health and Family Welfare, New Delhi to ARKB. The authors sincerely thank Dr. T.C. Nag, Associate Professor, Department of Anatomy, All India Institute of Medical Sciences, New Delhi, for his kind help in conducting the scanning and transmission electron microscopic studies. The authors express their sincere thanks to Dr. Philippe Belon, Director, Boiron Lab, Lyon, France, for kindly donating the Alc-200 for this work.

\section{References}

1. Ernst E. The current position of complementary/alternative medicine in cancer. Eur J Cancer 2003;39:2273-77.

2. Earnst E. Complementary or alternative therapies for osteoarthritis. Nat Clin Pract Rheumatol 2006;2:74-80.

3. Ricotti V, Delanty N. Use of complementary and alternative medicine in epilepsy. Curr Neurol Neurosci Rep 2006;6:347-53.

4. Simpson CA. Complementary medicine in chronic pain treatment. Phys Med Rehabil Clin N Am 2006;17:451-72.

5. Richardson MA, Straus SE. Complementary and alternative medicine: Opportunities and Challenges for cancer management and research. Seminars in Oncology 2002;29:531-45.

6. Chrystal K, Allan S, Forgeson G, Issacs R. The use of complementary and alternative medicine by cancer patients in New Zealand and regional cancer treatment center. New Zealand Med J 2003;116:1-8.

7. Molassiotis A, Panteli V, Patiraki E, Ozden G, Platin N, Madsen E, et al. Complementary and alternative medicine use in lung cancer patients in eight European countries. Complement Ther Clin Pract 2006;12:34-9.

8. Molassiotis A, Margulies A, Fernandez-Ortega P, Pud D, Panteli V, Bruyns I, et al. Complementary and alternative medicine use in patients with hematological malignancies in Europe. Complement Ther Clin Pract 2005;11:105-10.

9. Bensoussan M, Jovenin N, Garcia B, Vandromme L, Jolly D, Bouche $\mathrm{O}$, et al. Complementary and alternative medicine use by patients with inflammatory bowel disease: results from a postal survey. Gastroenterol Clin Biol 2006;30:14-23.

10. Joos S, Rosemann T, Szecsenyi J, Hahn EG, Willich SN, Brinkhaus B. Use of complementary and alternative medicine in Germany - a survey of patients with inflammatory bowel disease. BMC Complement Altern Med 2006;6:19. doi: 10.1186/1472-6882-619. http://www.biomedcentral.com/1472-6882/6/19.

11. Biswas SJ, Khuda-Bukhsh AR. Effect of a homeopathic drug, Chelidonium, in amelioration of p-Dab induced hepatocarcinogenesis in mice. BMC Complement Altern Med 2002;2:1-16.

12. Biswas SJ, Khuda-Bukhsh AR. Evaluation of protective potentials of a potentized homeopathic drug, Chelidonium majus, during azo dye induced hepatocarcinogenesis in mice. Indian $J$ Exp Biol 2004;42:698-714.

13. Biswas SJ, Pathak S, Bhattacharjee N, Das JK, Khuda-Bukhsh AR. Efficacy of a potentized homeopathic drug, Carcinosin-200, fed alone and in combination with another drug, Chelidonium-200, in amelioration of $\mathrm{p}$-Dab induced hepatocarcinogenesis in mice. J Altern Complement Med 2005;11:839-54.

14. Pathak S, Das JK, Biswas SJ, Khuda-Bukhsh AR. Protective potentials of a potentized homeopathic drug, Lycopodium-30, in ameliorating azo dye induced hepatocarcinogenesis in mice. Mol Cell Biochem 2006;258:121-31.

15. Daust R, Molnar F. Cellular populations and mitotic activity in rat liver parenchyma during azo dye carcinogenesis. Cancer Res 1964;24:1898-1909.

16. IARC (International Agency for Research on Cancer). On the evaluation of carcinogenic risk of chemicals to man. Group- $2 B$ 1987; 7:449.

17. Ohnishi S, Murata M, Degawa M, Kawanishi S. Oxidative DNA damage induced by an N-hydroxy metabolite of carcinogenic 4-dimethylaminoazobenzene. Jpn J Cancer Res 2001;92:23-9.

18. Merkulova TI, Kropachev KY, Timofeeva OA, Vasiliev GV, Levashova ZB, Ilnitskaya SI, et al. Species-specific effects of the hepatocarcinogens 3'- methyl-4-dimehylaminoazobenzene and ortho-aminoazotoluene in mouse and rat liver. Mol Carcinog 2005;44:223-32.

19. Biswas SJ, Khuda-Bukhsh AR. Cytotoxic and genotoxic effects of the azo-dye p-dimethylaminoazobenzene in mice: A time-course study. Mutat Res 2005;587:1-8. 
20. Siemiatycki J, Richardson L, Straif K, Latreille B, Lakhani R, Campbell S, et al. Listing occupational carcinogens: research Review. Environ Health Perspect 2004;112:1447-59.

21. NTP. Report on Carcinogens. (11th edn). Research Triangle Park, NC: National Toxicology Program. 2005 (Retrieved from http:// ntp.niehs.nih.gov/index.cfm?Objectid=32BA9724-F1F6-975E-7FCE 50709CB4C932.).

22. IARC (International Agency for Research on Cancer). Phenobarbital and Sodium salt. IARC monograph 2001;79:161.

23. White SJ, McLean AEM, Howland C. Anticonvulsant drugs and cancer, A cohort study in patients with severe epilepsy. Lancet 1979;ii:458-61.

24. Lee GH. Paradoxical effects of phenobarbital on mouse carcinogenesis. Toxicol Pathol 2000;28:215-25.

25. Kinoshita A, Wanibuchi H, Morimura K, Wei M, Shen J, Imaoka S, et al. Phenobarbital at low dose exerts hormesis in rat hepatocarcinogenesis by reducing oxidative DNA damage, altering cell proliferation, apoptosis and gene expression. Carcinogenesis 2003;24:1389-99.

26. Biswas SJ, Pathak S, Khuda-Bukhsh AR. Assessment of the genotoxic and cytotoxic potential of an antiepileptic drug Phenobarbital, in mice: A time course study. Mutat Res 2004;563:1-11.

27. Palekar SD, Sirsat SM. Studies on the hepatocyte in azo dye carcinogenesis. Indian J Exp Boil 1966;4:73-8.

28. Boericke W. Pocket Manual of Homeopathic Materia Medica Indian edn. Calcutta, India: Sett Dey and Co., 1976.

29. Kitagawa T, Sugano H. Enhancing effect of phenobarbital on the development of enzyme-altered islands and hepatocellular carcinomas initiated by 3'-methyl-4-(dimethylamino) azobenzene or diethylnitrosamine. Gann 1978;69:679-87.

30. Kitagawa T, Sugano H. Enhancement of azo-dye hepatocarcinogenesis with dietary phenobarbital in rats. Gann 1977;68:255-6.

31. Khuda-Bukhsh AR. Towards understanding molecular mechanisms of action of homeopathic drugs: An overview. Mol Cell Biochem 2003;253:339-45.

32. Khuda-Bukhsh AR. Laboratory research in homeopathy: pro. Integr Cancer Ther 2006;5:320-32.

33. Homeopathic Pharmacopoeia of India. Ministry of Health. Government of India Press, Coimbatore-641019: Controller of Publications, 1971;1:165.

34. Pathak S, Bhattacharjee N, Das JK, Chaki Chowdhury S, Roy Karmakar S, Banerjee P et al. Supportive evidences for anticancerous potential of an alternative medicine in hepatocarcinogenesis of mice. Res Com Med. June issue, 2007; 14:132 (DOI:10.1159/ 000102007).

35. Plaa GL, Amdun AM, Doull J, Klasser CD. Toxic responses of the liver, 4th edn. London UK: Pergamon Press, 1991.

36. Chan KY, Wong N, Lai PB, Squire JA, Macgregor PF, Behesthi B, et al. Transcriptional profiling on chromosome $19 \mathrm{p}$ indicated frequent down regulation of ACP5 expression in hepatocellular carcinoma. Int $J$ cance 2005;114:902-8.

37. Reichling JJ, Kaplan MM. Clinical use of serum enzymes in liver diseases. Dig Dis Sci 1988;33:1601-14.

38. Wiwanitkit V. High serum alkaline phosphatase levels, a study in 181 Thai adult hospitalized patients. BMC Family Practice 2001; 2:2 (retrieved from http://www.biomedcentral.com/1471-2296/2/2).

39. Marnett LJ. Lipid peroxidation-DNA damage by malondialdehyde. Mutat Res 1999;424:83-95.

40. Mishra S, Sharma DC, Sharma P. Studies of biochemical parameters in breast cancer with and without metastasis. Indian $J$ Clin Biochem 2004;19:71-5.

41. Dreher D, Junod AF. Role of oxygen free radicals in cancer development. Eur J Cancer 1996;32A:30-8.

42. Jungst C, Cheng B, Gehrke R, Schmitz V, Nischalke HD, Ramakers $\mathbf{J}$, et al. Oxidative damage is increased in human liver tissue adjacent to hepatocellular carcinoma. Hepatology 2004;39:1663-72.

43. Balasubramanian S, Kowdley KV. Effect of alcohol on viral hepatitis and other forms of liver dysfunction. Clin Liver Dis 2005;9:83-101.

44. Czeczot H, Scibior D, Skrzycki M, Podsiad M. Glutathione and GSH-dependent enzymes in patients with liver cirrhosis and hepatocellular carcinoma. Acta Biochem Pol 2006;53:237-42.

45. Maclaughlin BW, Gutsmuths B, Pretner E, Jonas WB, Ives J, Kulawardane DV, et al. Effects of homeopathic preparations on human prostate cancer growth in cellular and animal models. Integr Cancer Ther 2006;5:362-72.

46. Jonas WB, Gaddipati JP, Rajeshkumar NV, Sharma A, et al. Can homeopathic treatment slow prostate cancer growth? Integr Cancer Ther 2006;5:343-9.

47. Adams LS, Seeram NP, Hardy ML, Carpenter C, Heber D. Analysis of the Interactions of Botanical Extract Combinations Against the Viability of Prostate Cancer Cell Lines. eCAM 2006;3:117-24.

48. Padmavathi B, Rath PC, Rao AR, Singh RP. Roots of Withania somnifera Inhibit Forestomach and Skin Carcinogenesis in Mice. Evid Based Compliment Alernat Med 2005;2:99-105.

49. Miller SC. Echinacea: a Miracle Herb against Aging and Cancer? Evidence In vivo in Mice. Evid Based Compliment Alternat Med 2005;2:309-14.

50. Pathak S, Multani AS, Banerjee P. Ruta 6 selectively induced cell death in brain cancer cells but proliferation in normal peripheral blood lymphocytes: A novel treatment for human brain cancer. Int J Oncol 2003;23:975-82.

51. Khuda-Bukhsh AR. Potentized homeopathic drugs act through regulation of gene expression: a hypothesis to explain their mechanism and pathways of action in vivo. Com Ther Med 1997;5:13-46.

Received November 27, 2006; accepted May 8, 2007 


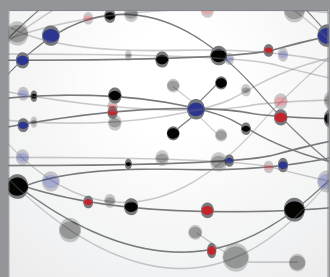

The Scientific World Journal
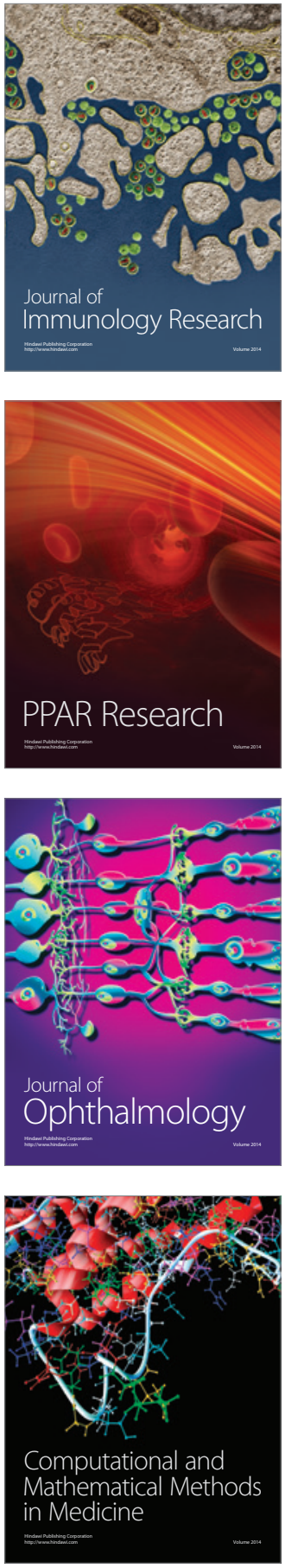

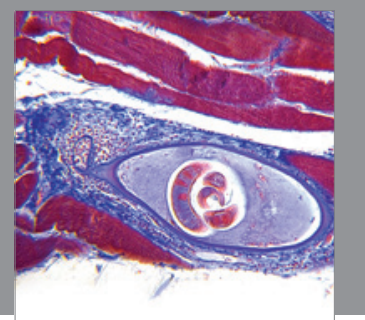

Gastroenterology

Research and Practice
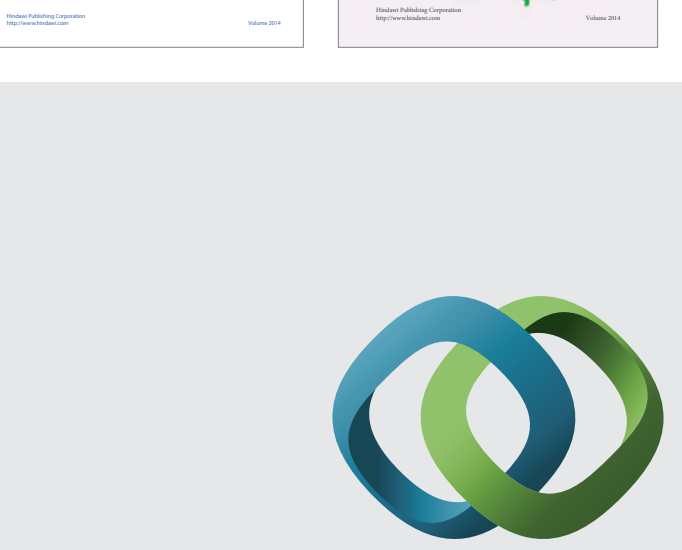

\section{Hindawi}

Submit your manuscripts at

http://www.hindawi.com
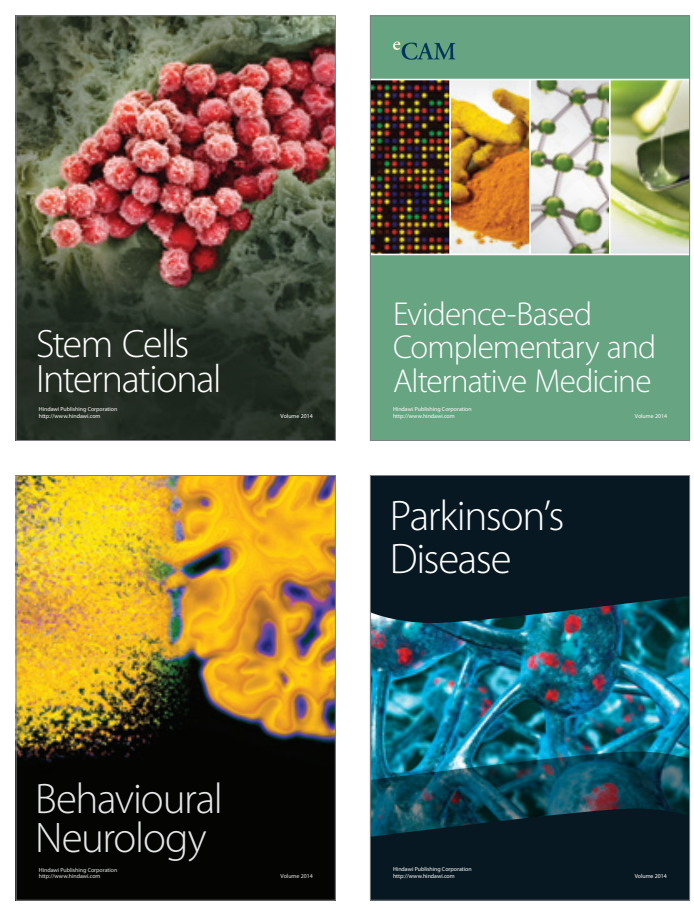

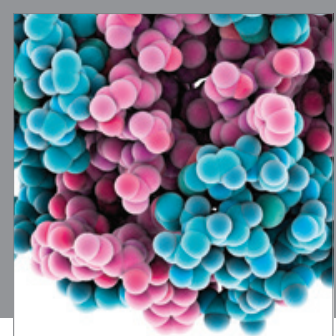

Journal of
Diabetes Research

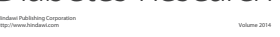

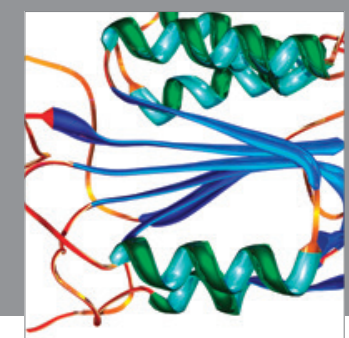

Disease Markers
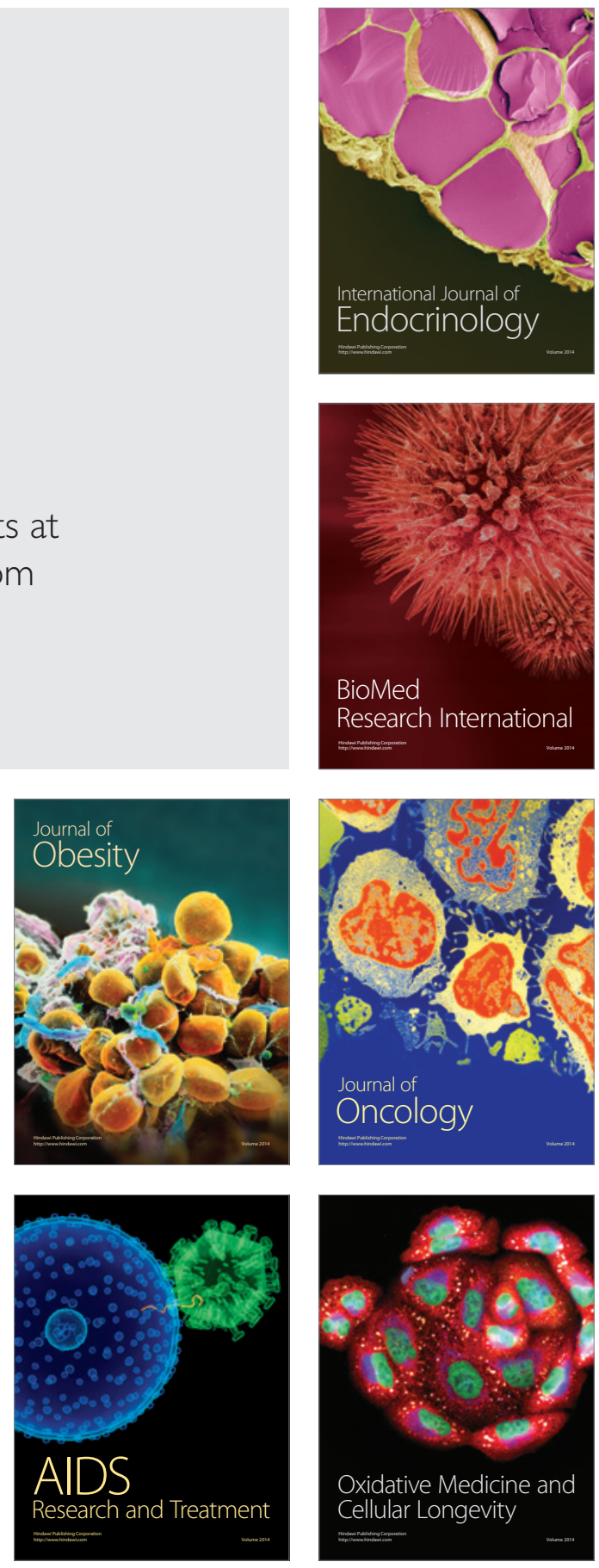